\title{
WHY RADICALISM IN PESANTREN? A CASE STUDY OF ONE PESANTREN IN INDONESIA
}

\author{
Abdul Malik \\ State Institute of Islamic Studies, Mataram, Indonesia (nakamalik@gmail.com) \\ Ajat Sudrajat (Corresponding author) \\ Universitas Negeri Yogyakarta, Indonesia (ajat@uny.ac.id) \\ Mifedwil Jandra \\ Islamic State University of Sunan Kalijaga Yogyakarta, Indonesia \\ (jandraj6@gmail.com) \\ Miftachul Huda \\ Faculty of Islamic Civilisation, Universiti Teknologi Malaysia \\ (halimelhuda@gmail.com)
}

\begin{abstract}
This research aims at revealing the issue of radicalism associated with pesantren (Islamic Boarding School) in Bima regency, Indonesia. The issue of radicalism is associated with some pesantren in Bima, which are allegedly developed radicalism. This issue sparks due to some Moslem scholars (ustad) and pesantren officials in Bima who are allegedly involved in terrorism cases. The widespread issue of terrorism which is associated with pesantren raises a stigmatization that pesantren is considered an educational institution that supports radical values. The method used in this research is a qualitative-phenomenological method. This method seeks to provide answers to the question of why a radical stigmatization is addressed to some pesantren, particularly in Bima Regency. The results of the research show that there are some aspects dealing with pesantren which become indicators of radical stigmatization. These aspects include: curriculum, exclusive understanding and religious attitudes, and indoctrinate learning processes. Therefore, to reduce the emergence of radicalism in pesantren, it is necessary to have a dialogue between the government and religion figures, especially the officials of pesantren.
\end{abstract}

Keywords: pesantren, stigmatization, radicalism

\section{INTRODUCTION}

Bima Regency, although it is not well-known as a Moslem pupil region, has many pesantren. The oldest pesantren in West Nusa Tenggara (NTB) province is Darul pesantren founded in 1768. It becomes a forerunner for the development of Islamic 
Boarding Schools in Bima. Its birth has inspired a number of figures in Bima to establish pesantren. The pesantren are generally traditional affiliating with ahlu alsunnah wa al-jamaah. The development continues over time, until reaching 63 pesantren which spread all over Bima Regency and City.

After bomb explosions occurred in one of the pesantren (U) on $11^{\text {th }}$ July 2011 killing a Moslem scholar F, pesantren in Bima are monitored by the Government. Pesantren $\mathrm{U}$ was allegedly developed radicalism and accused as a terrorist pesantren. The impact of the incident is that some officials of pesantren $U$ were arrested, and some of them were surrendered, and jailed. The issue of pesantren $U$ involvement in terrorism quickly spred to the society.

The case of pesantren $\mathrm{U}$, in fact, has affected other pesantren; for example, pesantren $\mathrm{M}$ which is located at same area. This is the reason for police to monitor those two pesantren. Viewed from educational aspects, the background of establishing pesantren $\mathrm{U}$ is not far different from pesantren $\mathrm{M}$, namely, to create $d a^{\prime} i$ (Moslem scholars) who strongly hold the Koran and hadith with jihad spirit to uphold it. Other objectives of establishing both pesantren are to re-purify aqidah (Islamic creed) of people and doing jihad to enforce Islamic Law in Indonesia. The awareness to enforce this Islamic Law makes both contradict with ideology of Indonesia.

Pesantren U was established based on manhaj dakwah wal jihad and referred to the Koran and hadith. With regard to this, the pesantren does not implement a national curriculum. One of consequences is that, since it was founded in 2004 up to now, pesantren $U$ does not have a license like other pesantren in general. Therefore, when bomb case sparked in the Islamic Boarding School in 2011, the government stated that the pesantren $\mathrm{U}$ is excluded from pesantren.

$\mathrm{SB}$, one of pesantren $\mathrm{U}$ officials, said: "pesantren $\mathrm{U}$ is a pesantren which holds dakwah wal jihad principle, there is no correlation to radical teachings. This pesantren is opened for anyone who wants to study" (Interview, 29/09/2015). Based on the statement above, pesantren $U$ is an opened school, because its religious mission is to enforce Islamic Law in society openly so that the objectives of religious missions could be achieved. Results of observation conducted by the researcher 
indicate that this pesantren has visions to enforce Islamic Law in Indonesia through open religious missions.

Meanwhile, the establishment of pesantren $M$ cannot be separated from four Moslem scholars, namely, MY, JB, BE, and T. They are worried about the people of Bima who have abandoned their indigenous identity which is based on Islamic principles. The Islamic culture in Bima Regency began to be replaced by pop cultures. Due to this reason, BE and his friends established pesantren as alternative educational media for Islamic society and as their place for proselytizing. In 2001, those four Moslem scholars established M Foundation in N Village, B-Bima Subdistrict and chose MY as the first Foundation Leader. The main focus of the foundation is establishing the Koran reading and Islamic learning forum. At the same time, M Foundation became a gathering place for activists of salaf Islamic groups, which is recently known as Jamaat Ashorut Syariah (JAS).

This organization is a media for proselytizing which aims at teaching people about true aqidah (Islamic creed), as had been taught by The Prophet of Muhammad and previous generations of Islam. Another objective is to spread religious understanding of salaf. This objective becomes a base for establishing pesantren $\mathrm{M}$ located in the $\mathrm{T}$ village. Pesantren $\mathrm{M}$ establishment requires a long and tiring struggle. $M$ pesantren is very near and even a part of pesantren $U$. Therefore, ideologically, both pesantren have similarity, so that pesantren $\mathrm{M}$ is also alleged as a radical pesantren.

\section{The scope of radicalism}

The pesantren are generally known as an Islamic educational organization which is simple, open, as well as grow and develop with surrounding society. Along with era development, pesantren has experienced many changes. One of the changes is that religious radicalism issue is often associated with the educations implemented the pesantren. The stigmatization of pesantren as radical educational institutions is a new phenomenon in pesantren tradition; therefore it is difficult to describe it without sufficient data. It seems necessary to study general indicators of radicalism to understand radicalization which are allegedly occurred in both pesantren. 
Referring to the political view of America, general characteristics of radicalism include individuals or groups desiring to establish Islamic state, enforce Islamic Law, study and perform jihad fisabilillah. Thus, if there are individuals, groups and educational institutions which perform those three actions, they can be categorized as radicalism. Based on this view, both pesantren can be categorized as radical groups, although Western Scientists and Islam have different views on radical concepts. Esposito (1997: 21), for example, defines the term radical as a transformation attitude and Islamic resurrection activities for performing changes which are relevant with Islamic teachings. In addition, in context of religious behavior, radical may mean strong and solid religious attitude on strict religious bases.

In addition, radicalism is often considered similar to fundamentalism. Fundamentalism becomes radical or revolutionary when a desire to reform society is described in terms of politics (Roy, 2005:25-26). This definition places radical Islamic groups as anti-system group. Although radicalism is not always associated with a movement or actions, but it is a conception of faith system (ideology). Therefore, in a specific context, fundamentalism is spirit of thinking and movement for religious radicalism.

According to Armstrong (2013:113), radicalism always exists in every religion with many followers in the world, not only Christian and Islam, radicalism is also found in Hindu, Buddha, Jew, and Confucianism. Even, according to Graudy (Ismail, 2001:10), radicalism is not only limited on faith, but also in politics, social, and culture. Therefore, radicalism is views which are upheld based on beliefs, religion, politics and culture.

In its development, radicalism is frequently defined as a political Islamic movement. Islam tends to become a movement ideology to achieve specific goals. Therefore, the meaning of radical is biased for example, Miller (2007:12) states that radical Islam will be defined as an Islamist Movement that seeks to use violence or violent rhetoric to gain power with the goal of creating an Islamic state, based on the sharia. According to Miller, there are two characteristics of Islamic radical in terms of goals, namely using violence to achieve goals and establishing Islamic state or apply Islamic sharia formally. 
Based on some of the definitions above, both pesantren, in this study, can be categorized as radical. This is based on the research findings, such as desire to perform an innovation (anti-system) and strong religious attitude associated with enforcement of Islamic law (sharia) and jihad fisabilillah teaching. The findings also show that, regardless of the rejection of the negative stigma, there are some indicators which show a correlation between pesantren $\mathrm{U}$ and $\mathrm{M}$ and radicalism (terrorism). According to Esposito's idea (1997:35) regarding radicalism viewed from positive perspective, pesantren can be defined as an Islamic educational institution which teaches fundamental issues in religion.

\section{Education in Pesantren}

The simple definition of traditional Islamic education, according to Dhofier (2015:22), is an Islamic education which is still associated with thoughts of experts in fiqh, hadits, tafsir, aqidah, and tasawuf developing from $7^{\text {th }}$ century to $13^{\text {th }}$ century. This kind of understanding has colored Islamic education in pesantren along history up to now, although, recently pesantren claim as modern pesantren (Dhofier, 2015:41).

Referring to the great tradition of pesantren mentioned above, there are three issues which are automatically binding to the definition of pesantren as a traditional educational institution: first, the type of of Islamic thinking or teaching and values which are taught; second the existence and role of religious clerics (kyai); and third culture which includes all forms of tradition practiced in the Islamic boarding schools. The main indicator of pesantren as a traditional Islamic educational institution is the existence of kyai, others are only complementary components.

In its development, pesantren can be categorized into three types, namely traditional pesantren (salaf), modern (khalaf), and combination of both. However, educational and cultural process of pesantren from the two main types, has fundamental differences. Therefore, in this study, both are described separately. In addition, in this study, both types of pesantren become horizon and analytical framework toward radicalism issues in pesantren education.

Ideologically, the belief systems followed and developed by pesantren are referring to ahlu al-sunnah wa al-jamaah and manhaj salafush shaleh. According to 
Abdullah Bin Abdil Hamid Al-Atsari (2015:47) in the book of Aqidah Salaf Ahlus Sunnah wal Jama'ah, ahlus sunnah wal jama'ah include people who strongly hold the sunnah of Muhammad Prophet, his companions, and people following the Prophet (tabiin), following the Prophet companion's faith, words and actions by istiqamah on the basis of ittiba' and avoid bid'ah.

\section{The Correlation between Pesantren $U$ and $M$ and Radicalism}

Radical stigmatization of both pesantren is caused by a belief of some people and government stating that both pesantren have correlation with radicalism. This research has found that there are some forms of correlation which are the relevant.

a. Ideological correlation with radical Islamic figures

Pesantren $\mathrm{M}$ and $\mathrm{U}$ ideologically have a relationship with religious clerics who are allegedly performing radicalism in understanding Islamic teaching. Some of the religious clerics consist of: Hasan al-Banna, Sayyid Qutb, Maududi, Muhammad Abduh, and Muhammad Ibn Abdul Wahhab. Their tafsir (Koranic interpretation), holy books, and understanding become main references in learning at pesantren. For example, the concepts of khilafah Islamiyah, jihad, and Islamic sharia developed in pesantren have similarity to their views. For this reason, both pesantren are allegedly affiliated with radical Islamic groups.

One of the ways to know the ideology followed by an educational institution is to study their curriculum. For example, pesantren $U$ applies a local curriculum $100 \%$ although there some additional lessons such as mathematics, Indonesian language, and English. The additional lessons are elective because they are provided for pupils who want to follow equality tests. This is also practiced in pesantren M. This policy results in exclusive impression for both pesantren.

With regard to this study, since the object of the study is an informal educational aspect (pesantren systems), the curriculum described in this study refers to the curriculum of pesantren. Generally, the curriculum contents pesantren of $U$ and $\mathrm{M}$ which are allegedly associated with religious radicalism issues include tauhid (aqidah Islamiya), jihad fisabilillah, and enforcement of Islamic Law. Those three aspects are interrelated one another, the following describes those three aspects: 


\section{1) Tauhid (aqidah Islamiyah)}

Tauhid not only deals with how human prays to Allah, but also it gives understanding on the needs to keep the purity of tauhid from polytheism. The Islamic Boarding Schools emphasize that the main pillar of human faith is Tauhid; a strong and pure belief existing in heart indicating that the only God creates, maintains, and discontinue life.

Based on the understanding above, Moslem scholars divide polytheism into two. First, polytheism which deals with ubudiyah, for example, prohibition to pray, rely on, request to and depend on something/object like burial polytheism and etc. Second, specific polytheism such as making law which is not relevant with Islamic Law. In other words, humans do not implement Islamic law, for example, punishing the thief by cutting their hands. The government changes this Islamic rule by imprisoning the thief. It means that humans have made a new law for punishing a thief, where implementing double laws is prohibited in Islamic law. This also belongs to the practice of polytheism because it competes with the God's Law (Interview with M Moslem scholar, 11/10/2015).

The interpretation of the law above is based on the verse "innilhukmu illallah", which means the absolute law is indeed the God's Law. This interpretation is not always appropriate because according to some Moslem scholars, the law in the Islamic discourse is divided into three parts. First, God's Law as stated in the Koran and Hadith; second, qadi' law, a law which is formulated by judge in a court; and third, customary law, a law established by traditional figures and implemented by specific society.

The Moslem scholar's views above believe that all human-made laws, including the 1945 Indonesian Constitution (UUD 1945) and Indonesia's state Ideology of Five Principles (Pancasila) contradict with Tauhid in Islam. If the laws are made by human, they must be rejected. When someone accepts and implements the human-made laws, they are called a polytheist. The groups of Moslems who have this kind of understanding will easily judge others as infidels (kafir). Furthermore, this takfiri (easily judging others as infidels) may lead to anti-social attitude or behavior which can trigger conflicts in the society. 
According to Abegebriel (2004:23), the Islamic understanding which tends reject human-made laws is caused by, first, a misunderstanding of messages presented in the Koran; second, awkwardly and textually interpreting the Koran verses. The interpretation of sentences in the Koran verses is supposed to link to other sciences, such as, Arabic language, Ulmul Quraan, fiqh, Asababul Nuzul, etc. Basically, solving the live problems should refer to the Koran and Hadith. With regard to this, the Koran and Hadith should not only be interpreted textually, but also contextually.

In addition, Abegebriel (2014: 25-26) states that the textual-based religious understanding performed by Moslem scholars in both Islamic Boarding Schools is not far different from the Islamic group of Khawarij and Wahabi in understanding nash. They understand textually and partially so that the law they formulate is not deep and tend to be sect-oriented. It triggers to judge that other perspectives which are different from him are wrong.

With regard to the case of tauhid, some religious groups often provide biased meaning. The excerpt of the Koran verse innalhukmu ilallah (no law but God's Law) is generally and contextually interpreted by Moslem scholars in those pesantren. That verse excerpt seems do not have a space to interpret. Therefore, this kind of tauhid understanding is automatically influences the understanding of religion which develops in those Islamic Boarding Schools, for example, the case of nation, law, and leadership.

Regardless of those difference, based on the explanation of JB Moslem scholars (Interview 11/10/2015), the Moslem scholars in those boarding schools instill the best foundation for the whole human life, namely Islamic Law. A nation will not be prosperous as long as they still implement a secular law (1945 Constitution and Pancasila). Therefore, we need to make people aware that Islam is the only solution for all the nation problems. The teaching of tauhid performed by those Islamic Boarding Schools is one of the strategies to make people aware that following thagut (human-made law) is the greatest sin.

The officials of both pesantren think that upholding aqidah islamiyah (tauhid) through education in pesantren and dakwah fisabilillah is a must. In other words, it cannot be negotiated. Strong affirmation, commitment, and faith regarding this case 
lead to the judgement that those pesantren are radical. According to Roy (2005:11), Islamic radicalism is a political Islamic movement, that is, putting Islam as a political organization. It is an Islamic purity revitalization movement.

One of purity movement activities is the study of aqidah islamiyah performed by both Islamic Boarding Schools through educational process. The study of aqidah islamiyah which emphasizes the importance of tauhid purity without proper understanding on both concepts will result in differences and serious conflicts in the family and society.

The example of a case which occurs in Jamaah Anshorut Tauhid (JAT) based on the explanation of JB (Interview 11/10/2015) is when one believes that the current government is thagut (the government does not implement Islamic law), all policies issued by the government are illegal such as the law which rules a civil servant and participation in general elections. This strict understanding does not make Moslem Scholar resign from civil servants. Moreover, some pesantren pupils against their parents because they participate in general elections.

\section{2) Islamic Law}

The teaching of tauhid demands pesantren $\mathrm{U}$ and $\mathrm{M}$ to instill the importance of enforcing Islamic Law in the learning process. The Islamic Law in this case include all the laws which are based on the Koran and hadith. Both pesantren view that law is not only dealing with halal, haram, mubah, and makruh but also the purity of the tauhid itself. Therefore, the understanding of Islamic Law enforcement instilled to the pupils in those Islamic Boarding Schools rejects any human-made law.

Endang Turmudi (2005:19-21) states that the rejection of some Islamic groups on Pancasila as law is influenced the current social conditions which develop in the society. The groups believe that Indonesian is savage because most of them legalize all manners. It is very difficult to get justice because all "can be solved using money"; therefore sleaze occurs everywhere. This condition will not change unless law and Islamic values are implemented and the government provides strong support.

The recommendations of implementing Islamic Law as a solution of the nation's problems not only come from the Islamic groups which are allegedly radical 
but also from other Islamic groups. The different of those groups is that pesantren often teach Islamic values using provocative and expressive manners as if giving emphasis that Indonesia is now experiencing a crucial condition, so that the enforcement of Islamic Law is badly needed.

The motivation and reason of enforcing Islamic Law is an anti-thesis of the current government system failure. The government failures in all aspects are reality, for example, law inequality and moral degradation. With regard to this, some groups of people offer a solution by implementing Islamic Law. Groups which have a spirit to criticize national problems and actively enhance the enforcement of Islamic Law are called as Islamists, whereas groups which tend to reject Islamic Law enforcement are called nationalists.

The new generation of Islamists such as the Moslem scholars in both Islamic Boarding Schools believes that Islamic Law is the only solution to create equality and realize people's wellbeing because Islam manages the cases in the world and hereafter. With regard to this, Moslem scholars have a duty to give whole understanding to the pupils on importance of enforcing God's Law on earth.

The process of Islamic Law implementation in the Islamic Boarding Schools was conducted through education. Those pesantren do not utilize violence in applying Islamic Law because Moslem scholars realize that the understanding of the society on religion is varied. Therefore, pesantren prioritize education and proselytizing as strategies in socializing the implementation of Islamic Law values to pupils and people in general.

Along with that awareness and refer to the opinion of BE (Interview 17/08/2015), the education in pesantren is intended to proselytize the Islamic teachings and pupils are expected to share their knowledge they get from the pesantren schools to the society. Therefore, Moslem scholars do not expect salary but they donate their money for the management of pesantren. The importance of Islamic Law enforcement emphasized in the curriculum of both pesantren automatically rejects national curriculum which they consider secular. The national curriculum is allegedly developed by groups of ansharut thagut (thagut supporter). The groups are the opponents of ansharut sharia (supporter of God's Law). 
The ideology of Pancasila in the perspective of pesantren does not accommodate the essence of Islamic teaching yet; therefore, ideology of Pancasila and 1945 Constitution are categorized as a part of ansharut thagut. Moreover, the concept of nationalism tends to divide Islamic people. Therefore, the concepts developed in pesantren tries to revise the nationalism concept, which in many cases, may cause the conflicts between the Moslem people. In brief, any nation concept and leadership which are not based on Islamic teaching belongs the groups who support thagut (ansharut thagut).

\section{3) Jihad Fisabilillah (fiqh jihad)}

Instilling the importance of Islamic Law enforcement in pesantren causes pupils having a strong spirit to enforce Islamic Law. Therefore, they will defend and oppose the challenges which hamper this sharia enforcement. In this context, Jihad Fisabilillah is often interpreted as physical reactions.

The teaching materials regarding Jihad Fisabilillah are deeply elaborated on fiqh jihad, for example, fiqh jihad lesson also teaches ahkamuddimma i.e. law of struggle. This material is taught to grade III of Madrasah Aliyah. The goal of this material is to complement pupil's understanding on the issue of Jihad fi sabilillah. In the discussion of ahkamuddimma, there are more specific sub-themes, such as, time and condition to do Jihad, and the people to whom we should fight and how we perform self-defend when fighting.

With regard to the people to whom we should fight sub-theme, it is stated in discussion of law for people who hamper Islamic Law enforcement or Islamic proselytizing as presented in the Koran, Surah Ibrahim, paragraphs $2-3$, which means: "Allah to Whom belongs all that is in the heavens and all that is in the earth! And woe unto the disbelievers from a severe torment. Those who prefer the life of this world instead of the Hereafter, and hinder (men) from the Path of Allah (i.e.Islam) and seek crookedness therein - They are far astray”.

The paragraph in the Koran above explains that individuals or groups of people who breaks God's Law by hampering human in the God path are included as human who deviates far. According to the understanding of most Moslem scholars in pesantren $\mathrm{U}$ and $\mathrm{M}$ as stated by TQ (Interview 12/09/2015), the paragraph confirms 
that there is an individual or a group of people who want to follow the instruction/teaching of God but there is also an individual, a group of people, or a nation that hampers human to be in the God's path, and motivate the people to the stay away from the God's instruction so that they will be misfortune.

Based on the results of Interview and field observations, the learning of Jihad fi sabilillah performed in the pesantren focuses on the initial understanding of law and duty to do Jihad for Moslems. Moreover, the learning of Jihad is directed to the issues dealing with duty of Moslems to implement God's laws and duty to keep their beliefs in all situations and conditions. In other words, Jihad is not emphasized on physically opposing the government (authority, institution, and district). However, the understanding developed in those pesantren clearly contradicts with the current government.

Conceptually, Moslem scholars realize the difference between dar al-salam and dar al-harb, nevertheless they do not perform the attack against the government due to the situations and conditions. Jihad in a physical perspective is still directed at lower scales, for example, at the society and family. Dar al-salam is a joined goal for Moslem scholars although this goal cannot be realized yet through Jihad fi sabilillah at this moment. Therefore, the urgent missions held by Moslem scholars currently are to socialize and give understanding to people on importance of enforcing God's laws in a daily life. Based on Interview with $\mathrm{JB}$, after people realize the implementation of the God's laws comprehensively (kaffah), Jihad fi sabilillah will be addressed to the authorities or government.

\section{Correlation between Pesantren and Terrorism Case in Bima Regency}

Factually, both pesantren have a correlation with some terrorism cases taking place in Bima Regency from 2011 to 2014. The cases involved some Moslem scholars who taught in the pesantren, even, until now, there are some Moslem scholars in those pesantren who are jailed due to terrorism allegation. Therefore, radical stigmatization addressed to pesantren $\mathrm{U}$ and $\mathrm{M}$ cannot be avoided. Although the cases are considered as political issues, this fact cannot be accepted by some people in the society and the people in those pesantren. 
The correlation of $\mathrm{U}$ and $\mathrm{M}$ pesantren with radicalism can be described through radical indicators that can be found in the pesantren.

\section{Indicators (characteristics) of Radicalism in Pesantren of $U$ and $M$}

Based on the definitions and concepts of radicalism described above, there are some factors in the pesantren which can be allegedly as radical elements.

1) The sources of knowledge developed in those pesantren refer to the conservative contemporary ulama;

2) The interpretation practiced in understanding the Koran and Hadith tends to be textual, rigid and strict;

3) The religion understanding tends to be exclusive, truth claim, fanatic, subjective, and normative;

4) The education Model tends to be indoctrinate, exclusive, provocative and prejudice;

5) The curriculum emphasizes on aqidah islamiyah (tauhid) materials, Islamic Law enforcement, and dakwah wal Jihad fi sabilillah;

6) The personality tends to be closed, calm, militant, and uneasy to communicate with outsiders;

7) The goals of proselytizing movements include revitalization, religion purification, counter culture and rejection of secular and liberal systems;

8) The Moslem scholars and officials of pesantren are the graduates from pesantren which are associated with terrorism cased;

9) U Islamic Boarding School does not have a license to issue a graduate certificate;

10) The boarding schools do not implement a national curriculum. The curriculum they use and develop in pesantren is managed internally by the officials and Moslem scholars.

Some indicators above can be found in both pesantren. Therefore, referring to the definitions of radical which develop currently, both pesantren can be categorized as radical pesantren. However, the Moslem scholars in those pesantren do not consider that some of the indicators are part of radicalism. On the other hand, the indicators are stigmatized as radical by some people and government. 
Radicalism in pesantren is not only caused by some factors mentioned above but also many other factors, for example, political, social inequality, leader inequality, poverty, minimum understanding of religion, and empathic attitude against other Moslems tyrannized by infidels. According to the researchers, those factors do not have great significance. The strongest factors which rise radical stigmatization for both pesantren are the allegation that those pesantren have relationship with radical religious organization outside pesantren. The following is described the relationship of pesantren $\mathrm{U}$ and $\mathrm{M}$ with radical Islamic organizations.

\section{The relationship of Pesantren with JAT and JAS Islamic organization}

The majority of Moslem scholars and officials in those pesantren have relationship with Islamic organizations such as organization of Jama'ah Islamiyah (JI). This organization is suspected by government and the world as a radical Islamic organization. The relationship between the pesantren and the Islamic organization is in the form of intellectual chains, because some Moslem scholars and officials in the pesantren $\mathrm{U}$ and $\mathrm{M}$ are alumni of pesantren under the control of Jama'ah Islamiyah (JI) organization.

Furthermore, the relationship between $\mathrm{U}$ and $\mathrm{M}$ pesantren and radicalism is indicated by the intensive relationship between the pesantren and Islamic organization of JAT (Jama'ah Anshorut Tauhid) and JAS (Jama'ah Anshorut Syaria) which are allegedly having radical concepts.

In general, Islamic organizations which grow and develop in Bima include FPI (Islamic Defender Front), HTI (Indonesian Hizbut Tahrir), JAS, and Khilafat al Muslimin. There are some factors which enhance the establishment of those organizations such as the accommodation and expectation of the people in the society who want to purify Islamic teaching substances. Therefore, the factors are the reflection of needs and self-actualization on individual and group differences. Other factors are to block the influences of traditional, cultural and value such as secularism, pluralism, capitalism and socialism which are considered contradicting with Islamic values.

Some of the religious organizations have direct and indirect relationship with radicalism which develops in the pesantren, such as, MMI (Indonesian Defender 
Assembly), JAT and JAS. The indicators are involvement of individuals of those organizations who directly or indirectly influence the pesantren. One of involvements is being educators (Moslem scholars) and officials in both pesantren.

The relationship between religious organization and those pesantren cannot merely become a factor to judge that those pesantren are radical. However, viewed from the background and ideology, those Islamic organizations have been considered radical for long time. Some people and government think that radical ideology and religion understanding of the organizations are transferred to the pesantren through educational processes.

\section{The relationship of the Intellectual Network of the Moslem Scholars in Pesantren $U$ and $M$}

In $21^{\text {st }}$ century, leadership network systems in pesantren recently experience significant changes. A Moslem scholar is no longer key element or figure in establishing pesantren. Now, pesantren can be established by people who have a capacity in religious field and people who have ever studied in pesantren. In addition, the establishment of pesantren is not only depending on an individual (Moslem scholar) but it may be performed by a group of individuals autonomously. This autonomous concept or self-management is practiced in the management system of pesantren $\mathrm{U}$ and $\mathrm{M}$.

As a pesantren which is managed collectively, both pesantren experience leadership penetration through intellectual networks. The pesantren are established due to the joint awareness and agreement of some Moslem scholars who have ever learning Islamic teachings in pesantren. Therefore, the pesantren do not recognize kyai but ustad (moslem scholars), although the position and role of ustad is not far different from role of a kyai in context of pesantren existing in Java.

The radical stigmatization addressed to both pesantren can be viewed from intellectual chain pattern as implemented in pesantren in Java. The intellectual chain is also implemented by leaders and Moslem Scholars in pesantren $U$ and M. The majority of Moslem scholars and officials in those pesantren are alumni of a pesantren existing in Java Island which is under the influence of Jama'ah Islamiyah (JI) organization. This is relevant with the statement of $\mathrm{M}$ where radical allegation 
addressed to pesantren $\mathrm{U}$ and $\mathrm{M}$ is because Moslem scholars teaching in those pesantren are the alumni of pesantren under the control of Jama'ah Islamiyah (JI).

The explanation above indicates that intellectual networks of Moslem scholars who teach in those pesantren come from the education in the pesantren where the Moslem scholars have direct relationship with Jama'ah Islamiyah (JI) organization. The direct relationship in this case is relationship between Moslem scholars and pupils. In other words, the Moslem scholars in $\mathrm{U}$ and $\mathrm{M}$ pesantren are educated directly by individuals who are allegedly involved in Jama'ah Islamiyah (JI) organization.

Referring to Mbai (2014), the Jama'ah Islamiyah (JI) group is a transnational Islamic organization. There are many interpretations regarding this organization or movement. Some say that Jama'ah Islamiyah (JI) is an underground organization (tanzhim sirri) established by Abdullah Sungkar and Abu Bakar Ba'sir in 1976. Whereas Nasir Abbas as Jama'ah Islamiyah (JI) figure states that Jama'ah Islamiyah (JI) was established in 1993. In addition, some people say that Jama'ah Islamiyah (JI) is involved in some bomb cases, although some other people don't say so.

Regardless of the different interpretation above, the organization has a principle for Jihad and proselytizing. According to the document of Nidhom Asasu owned by Jama'ah Islamiyah (JI), a statute-like document in Chapter II, Article 4, Jama'ah Islamiyah (JI) is based on the Koran and Hadith relevant with with the understanding of salafush shalih. The target of jama'ah movement is to realize and enforce Daulah Islamiyah as basis to re-uphold Khalifah 'Alaa Minhajin Nubuwwah. Article 5 states that, to achieve target, jama'ah uses methods such as: da'wah, tarbiyah, amar ma'ruf nahi mungkar, moving, and Jihad fii sabilillah. Referring to the brief profile above, Jama'ah Islamiyah (JI) organization is allegedly a radical Islamic organization.

Considering the intellectual chain, pesantren $\mathrm{U}$ and $\mathrm{M}$ had a good relationship directly and indirectly with Islamic organizations which are allegedly radical. The fact indicates that all Islamic organizations enforce Islamic Law, establish khilafah Islamiyah, perform amar ma'ruf nahi mungkar, and Jihad Fisabilillah. Based on the intellectual chain, the majority of Moslem scholars in pesantren $U$ and $M$ have ever studied religion in one of pesantren which is under the control of Jama'ah Islamiyah 
(JI). Those pesantren are places for officials and Moslems scholars in the pesantren $\mathrm{U}$ and $\mathrm{M}$ to deepen their knowledge about Jihad, tauhid, ushul fiqh, and Islamic Law. In addition, most of Moslem scholars in pesantren $\mathrm{U}$ and $\mathrm{M}$ actively involves in JAT and becomes the forerunner of establishing JAS organization.

After JAT organization was splitted, JAS was established. Therefore, all Moslem scholars in pesantren $\mathrm{U}$ and $\mathrm{M}$ established a new organization under the leadership of NA. Then, JAS organization opened a branch office in Bima or Maktab. Maktab is like a secretariat which functions as a place to recruit new members and a place for meeting as well proselytizing. The research findings indicate that JAS organization becomes a basis and tarbiyah movement for Moslem scholars from both pesantren. The organizational activities include proselytizing and internal study forums. The results of study in the organization refer to the view of Jubair (Interview 17/08/2015) which are frequently practiced or taught in both pesantren.

\section{Implication into the academia-based intellectual potency}

Attempts to enhance the culture of learning with classroom management (Huda et al., 2017a) are required to address the strength of skillful adaptive references in the basis of technology-based interactive engagement (Huda et al., 2017b). Moreover, learning with sustainable-based mechanical rules (Huda et al., 2017c) associated with aids of rightful intention should point out the stability of awareness engagement (Huda and Kartanegara, 2015). Enhancing communication skills (Huda et al., 2017d) in the sense which took place the compassion basis (Huda et al., 2017e) to tackle conflict potency by embedding civic responsibility (Huda et al., 2017f) should be enlarged service including physical and spiritual basis (Huda et al., 2017g). Together with reenergizing comprehensive attainment of learning (Huda et al., 2016a; Maseleno et al., 2017) in penetrating the initiative of comprehending knowledge inquiry, the way of knowledge understanding (Huda et al., 2016b) needs to enhance the strengthening courage between teaching and learning referring to the basis of ethical enhancement (Huda et al., 2016c; Othman et al., 2016). In addition to the attempts in encouraging the strength of interaction based on virtual enhancement (Huda et al., 2017h), both professional and ethical engagement should become a pivotal role to enhance the religious acts in underlying the daily life interaction among the others (Huda et al., 
2017i). In terms of radicalism issues, it is necessary to expand the good model of interaction through social media in order to minimize the impact caused amidst the societal life.

\section{Conclusions}

The issue of radicalism is believed to give significant influences on the existence of pesantren of $U$ and $M$. There are some indicators which show the relationship between radicalism and pesantren. First, the sources of knowledge developed in the pesantren refer to contemporary-conservative Moslem scholars who were previously alleged as radical Ulama. Their views include: (1) the interpretation on the Koran and hadith tends to be textual, rigid, and strict; (2) The understanding on the religion tends to be exclusive, truth claim, fanatic, subjective and normative. Second, the majority of Moslem scholars and officials at both pesantren have relationship with Islamic organizations outside the pesantren. The related Islamic organization is Jama'ah Islamiyah (JI). This organization is alleged by the government and the world as a radical Islamic organization. The relationship between pesantren and the Islamic organization is on the intellectual network or intellectual chain because some Moslem scholars and officials at pesantren $\mathrm{U}$ and $\mathrm{M}$ are alumni of pesantren which are under the control of Jama'ah Islamiyah (JI) organization.

Specifically, the education implemented in pesantren $U$ and $M$ tend to be radical indicated by indoctrinate, hegemonic, authoritarian and exclusive learning processes. The research has found that the goals of the indoctrinate learning process include: first, it is intended to instill the ideology; second, it focuses on truth claim attitude; third, it focuses on pupils characters building; and fourth, it emphasizes on indoctrination for reinforcing the values.

Indoctrinate and exclusive education implemented in those pesantren emphasizes on one-way educational model, i.e. one Moslem scholar becomes a center of the educational process. The indoctrination learning process sets Moslem pupils as learning objects. This means that pupils are directed to accept what are being taught (take for granted). This learning process makes pupils rely on role of a Moslem Scholars. The exclusivity of the pesantren can be viewed from the references which are limited to books of certain Moslem scholars. The contents of 
curriculum implemented in the pesantren were determined internally and do not follow follow the national curriculum. In the perspective of ideology, the pesantren have an ideology which is based on closed religious understanding.

\section{REFERENCES}

Abegebriel, M. dkk, (2004). Negara Tuhan; The thematic Encyclopedia. Jakarta: SR-Ins Publishing.

Atsari, A. bin AH. (2015) Aqidah Salaf; Ahlul Sunnah wal Jama'ah. Jakarta: Pustaka Al INABAH

Armstrong, K. (2013). Berperang demi Tuhan, Fundamentalisme dalam Islam, Kristen, dan Yahudi. Bandung: Mizan.

Bronfenbrenner, U. (1979). The bioecological model of human development. Cambridge: Harvard University Press

Dhofier, Z. (2012). Tradisi pesantren, Studi tentang pandangan hidup kyai. Jakarta: LP3ES.

Esposito, J.L. (1996). Ancaman Islam mitos atau realitas, edisi revisi: Menggugat Tesis Huntington. Bandung: Mizan.

Huda, M., Sabani, N., Shahrill, M., Jasmi, K. A., Basiron, B., \& Mustari, M. I. (2017a). Empowering Learning Culture as Student Identity Construction in Higher Education. In A. Shahriar, \& G. Syed (Eds.), Student Culture and Identity in Higher Education (pp. 160-179). Hershey, PA: IGI Global. doi:10.4018/978-1-5225-2551-6.ch010

Huda, M., Shahrill, M., Maseleno, A., Jasmi, K. A., Mustari, I., \& and Basiron, B. (2017b). Exploring Adaptive Teaching Competencies in Big Data

Era. International Journal of Emerging Technologies in Learning, 12(3), 6883.

Huda, M., Jasmi, K. A., Basiran, B., Mustari, M. I. B., \& Sabani, A. N. (2017c). Traditional Wisdom on Sustainable Learning: An Insightful View From AlZarnuji's Ta 'lim al-Muta 'allim. SAGE Open, 7(1), 1-8.

Huda, M., Siregar, M., Ramlan, Rahman, S.K.A., Mat Teh, K.S., Said, H., Jamsari, E.A., Yacub, J., Dacholfany, M.I., \& Ninsiana, W. (2017d). From Live Interaction to Virtual Interaction: An Exposure on the Moral Engagement in the Digital Era. Journal of Theoretical and Applied Information Technology, 95(19), 4964-4972.

Huda, M., Jasmi, K. A., Embong, W. H., Safar, J., Mohamad, A. M., Mohamed, A. K., Muhamad, N. H., Alas, Y., \& Rahman, S. K. (2017e). Nurturing Compassion-Based Empathy: Innovative Approach in Higher Education. In M. 
Badea, \& M. Suditu (Eds.), Violence Prevention and Safety Promotion in Higher Education Settings (pp. 154-173). Hershey, PA: IGI Global. doi:10.4018/978-1-5225-2960-6.ch009

Huda, M., Jasmi, K. A., Alas, Y., Qodriah, S. L., Dacholfany, M. I., \& Jamsari, E. A. (2017f). Empowering Civic Responsibility: Insights From Service Learning. In S. Burton (Ed.), Engaged Scholarship and Civic Responsibility in Higher Education (pp. 144-165). Hershey, PA: IGI Global. doi:10.4018/978-1-52253649-9.ch007

Huda, M., Jasmi, K. A., Mustari, M. I., Basiron, B., Mohamed, A. K., Embong, W., \& Safar, J. (2017g). Innovative E-Therapy Service in Higher Education: Mobile Application Design. International Journal of Interactive Mobile Technologies, 11(4), 83-94.

Huda, M., Maseleno, A., Jasmi, K. A., Mustari, I., \& Basiron, B. (2017h). Strengthening Interaction from Direct to Virtual Basis: Insights from Ethical and Professional Empowerment. International Journal of Applied Engineering Research, 12(17), 6901-6909.

Huda, M., Haron, Z., Ripin, M. N., Hehsan, A., \& Yaacob, A. B. C. (2017i). Exploring Innovative Learning Environment (ILE): Big Data Era. International Journal of Applied Engineering Research, 12(17), 6678-6685.

Huda, M., Yusuf, J. B., Jasmi, K. A., \& Nasir, G. A. (2016a). Understanding Comprehensive Learning Requirements in the Light of al-Zarnūjī's Ta'līm alMuta'allim. Sage Open, 6(4), 1-14.

Huda, M., Yusuf, J. B., Jasmi, K. A., \& Zakaria, G. N. (2016b). Al-Zarnūjī's Concept of Knowledge ('ilm). SAGE Open, 6(3), 1-13.

Huda, M., Jasmi, K. A., Mohamed, A. K., Wan Embong, W. H., \& and Safar, J. (2016c). Philosophical Investigation of Al-Zarnuji's Ta'lim al-Muta'allim: Strengthening Ethical Engagement into Teaching and Learning. Social Science, 11(22), 5516-551.

Huda, M., \& Kartanegara, M. (2015). Islamic Spiritual Character Values of alZarnūjī's Ta 'līm al-Muta 'allim. Mediterranean Journal of Social Sciences, 6(4S2), 229-235.

Maseleno, A., Huda, M., Siregar, M., Ahmad, R., Hehsan, A., Haron, Z., Ripin, M.N., Ihwani, S.S., and Jasmi, K.A. (2017). Combining the Previous Measure of Evidence to Educational Entrance Examination. Journal of Artificial Intelligence 10(3), 85-90.

Ismail L. Ed. (2001). Ensiklopedi Tematik dunia Islam. Jakata: Serambi.

Roy, O. (2005). Geneologi Islam radikal. Yogyakarta: Genta Press.

Miller, R. (2007). "The Literatur of Terrorism.” Terrorism 11 September. E jurnal http://works.bepress.com/simonreobertmillar, 1, 63-87 
Kristeva, Nur. S. S. (2014). Sejarah teologi Islam dan akar pemikiran, Ahlussunah Wal Jama'ah. Yogyakarta: Pustaka Pelajar.

Asulistyo, (2012). “Asal mula radikalisme”. Jurnal Studi Hubungan Internasional, 2 , 12-13

(Interview, 29/09/2015)

(Interview, 11/10/2015)

(Interview, 11/10/2015)

(Interview, 11/10/2015)

(Interview, 17/08/2015) 